\title{
Linkages Perekonomian Bali
}

\author{
(The Linkages of Bali Economy) \\ Rizky Zulkarnain ${ }^{1}$, Nasiyatul Ulfah ${ }^{2}$ \\ 1,2 Badan Pusat Statistik \\ Jl. Dr. Sutomo No. 6-8 Jakarta 10710 \\ E-mail: zulqarnaen@bps.go.id
}

\begin{abstract}
ABSTRAK
Berbagai studi telah dilakukan untuk menganalisis dampak pengganda dari perekonomian Bali. Namun, studi-studi tersebut umumnya berfokus pada keterkaitan antar sektor menggunakan model Input-Output (IO). Padahal, perekonomian antar wilayah dapat saling bergantung melalui berbagai macam eksternalitas dan jaringan rantai suplai. Studi ini menganalisis perekonomian Bali tidak hanya berdasarkan hubungan antar sektor, namun juga mempertimbangkan hubungan ekonomi Bali dengan provinsi lainnya. Model yang digunakan adalah Inter Regional Input Output (IRIO). Tabel IRIO berukuran 17 industri x 34 provinsi serta 52 industri x 34 provinsi diperoleh dari Badan Pusat Statistik. Hasil analisis menunjukkan bahwa terdapat beberapa industri unggulan di Provinsi Bali, yaitu Penyediaan Akomodasi, Penyediaan Makan Minum, Angkutan Udara, Perdagangan, Industri Kayu dan Barang dari Kayu, Real Estate, Jasa Perusahaan, Jasa Lainnya, Ketenagalistrikan dan Informasi \& Komunikasi. Industri Ketenagalistrikan memiliki keterkaitan antar sektor dan dampak output yang paling besar diantara industri-industri di Provinsi Bali. Selanjutnya, analisis antar wilayah menunjukkan bahwa shock permintaan akhir di Provinsi Bali berdampak besar terhadap perekonomian provinsi-provinsi di Pulau Jawa, khususnya Jawa Timur. Di sisi lain, perekonomian Bali sangat dipengaruhi oleh shock permintaan akhir di Provinsi Nusa Tenggara Barat.
\end{abstract}

Kata kunci: backward linkage, forward linkage, input-output, IRIO, spillover

\begin{abstract}
Several studies have been conducted to analyze multiplier effect of Bali economy. However, those studies merely focus on intersectoral linkages using Input-Output (IO) model, whereas regional production activities could be interdependent through various externalities and supply-chain networks. This study aims to analyze Bali economy by considering interregional linkage as well as intersectoral linkage. This study employs Inter Regional Input Output (IRIO) model. The IRIO table (17 industries $x 34$ provinces and 52 industries $x 34$ provinces) was acquired from Statistics Indonesia (BPS). The results showed that there were several key sectors in Bali economy: Accommodation Service, Food Services, Air Transport, Trade, Manufacture of Wood and of Products of Wood, Real Estate, Business Activities, Other Services, Electricity, and Information \& Communication. Electricity industry had highest intersectoral linkage and output multiplier. Moreover, interregional analysis showed that final demand shock in Bali had significant impact to provinces in Java, especially East Java. On the other side, Bali economy was influenced by final demand shock in West Nusa Tenggara.
\end{abstract}

Keywords: backward linkage, forward linkage, input-output, IRIO, spillover

\section{PENDAHULUAN}

Integrasi ekonomi yang kuat, komprehensif dan berkelanjutan menjadi kunci keberhasilan pembangunan ekonomi. Integrasi ekonomi tersebut tidak hanya tercermin dari interaksi antar sektor dalam perekonomian, namun juga terlihat dari interaksi antara satu wilayah dengan wilayah lainnya. Sejak era desentralisasi, setiap daerah merupakan pengambil keputusan utama dalam pencapaian target-target pembangunan regional. Dengan demikian, pembangunan ekonomi diharapkan lebih optimal dan mengurangi disparitas antar wilayah.

Provinsi Bali memiliki peran strategis dalam perekonomian nasional, khususnya dalam sektor pariwisata. Bali menjadi salah satu destinasi wisata favorit dan bahkan dinobatkan sebagai pulau terbaik ke-2 di dunia untuk perjalanan dan relaksasi menurut majalah "Travel and Leisure" pada tahun 2015 (Antara \& Sumarniasih, 2017). Berdasarkan data BPS (2019), jumlah wisatawan mancanegara (wisman) yang datang ke Bali adalah sebanyak 6.27 juta orang. Jumlah tersebut mencakup $38.96 \%$ total wisman yang datang ke Indonesia. Hal ini menunjukkan bahwa Provinsi Bali berkontribusi besar dalam penerimaan devisa negara. Di sisi lain, Bali juga masih mengandalkan sektor pertanian sebagai sumber pendapatannya (Yuendini et al., 2019). 
Berbagai studi telah dilakukan untuk menganalisis keterkaitan antar sektor dan dampak pengganda dalam perekonomian Bali. Muchdie (1998) menganalisis keterkaitan sektor-sektor pariwisata dalam perekonomian Bali menggunakan tabel input-output. Antara (2000) mengkaji dampak pengeluaran pemerintah dan wisatawan serta investasi swasta terhadap kinerja perekonomian Bali menggunakan model Social Accounting Matrix (SAM). Purwanti (2002) meneliti keterkaitan sektoral dan dampak pengganda di Provinsi Bali menggunakan tabel input-output Bali tahun 1993 dan 2000. Antara (2008) menganalisis dampak pengganda usaha kecil sektor pariwisata terhadap pertumbuhan ekonomi Bali.

Penelitian-penelitian yang disebutkan sebelumnya hanya berfokus pada linkage antar sektor dalam menganalisis perekonomian Bali. Padahal, perubahan perekonomian di Bali tidak hanya berdampak untuk Bali sendiri, namun juga berdampak pada daerah lainnya. Perekonomian antar wilayah dapat saling bergantung melalui jaringan input-output dan berbagai macam eksternalitas (Tsukamoto, 2019). Sektor-sektor ekonomi di Provinsi Bali menggunakan input yang berasal dari provinsi lainnya. Begitu pula sebaliknya, output dari Provinsi Bali digunakan oleh provinsi lainnya.

Penelitian ini menganalisis perekonomian Bali tidak hanya berdasarkan linkage antar sektor, namun juga berdasarkan linkage antar provinsi. Analisis tersebut dapat dilakukan melalui kerangka Inter Regional Input Output (IRIO). Sejauh yang penulis ketahui, analisis perekonomian Bali menggunakan tabel IRIO belum banyak dilakukan. Setiawan (2007) pernah menganalisis peranan sektor unggulan terhadap pertumbuhan ekonomi di Provinsi Bali, Jawa Timur dan Nusa Tenggara Barat menggunakan tabel input-output multiregional. Namun, tabel input-output multiregional yang dibentuk terbatas untuk ketiga provinsi yang dianalisis. Berbeda dengan penelitian Setiawan (2007), penelitian ini menggunakan kerangka IRIO lengkap untuk 34 provinsi. Dengan demikian, penelitian ini dapat menganalisis dampak perubahan perekonomian di Provinsi Bali terhadap 33 provinsi lainnya, serta dampak perubahan perekonomian di provinsi lainnya terhadap Provinsi Bali.

\section{METODE}

\section{Sumber Data}

Data untuk penelitian ini bersumber dari Tabel Inter Regional Input Output (IRIO) Tahun 2016 yang disusun oleh Badan Pusat Statistik (BPS). Klasifikasi yang digunakan adalah 17 industri x 34 provinsi dan 52 industri x 34 provinsi. Transaksi yang digunakan adalah transaksi domestik, sehingga transaksi yang dicatat di masing-masing provinsi telah memisahkan komponen impor, baik impor antar provinsi maupun impor dari luar negeri. Selanjutnya, penilaian yang digunakan adalah harga produsen, sehingga transaksi yang dicatat masih mengandung pajak atas produk neto (belum memisahkan campur tangan pemerintah terhadap pajak dan subsidi atas produk).

\section{Koefisien Input dan Angka Pengganda}

Misalkan nilai uang arus barang dari sektor $i$ ke sektor $j$ dinotasikan dengan $z_{i j}$, output dari sektor $i$ dinotasikan dengan $x_{i}$, dan total permintaan akhir dari sektor $i$ dinotasikan dengan $y_{i}$, maka total output dari sektor $i$ dapat dituliskan sebagai berikut (Daryanto \& Hafizrianda, 2010):

$x_{i}=\sum_{j=1}^{n} z_{i j}+y_{i}$

Jika kita definisikan suatu koefisien input $a_{i j}=z_{i j} / x_{j}$, maka persamaan (1) dapat diubah bentuknya menjadi:

$x_{i}=\sum_{j=1}^{n} a_{i j} x_{j}+y_{i}$

Atau dalam bentuk vektor dan matriks dapat dituliskan sebagai berikut:

$\boldsymbol{x}=\boldsymbol{A x}+\boldsymbol{y}$

$\boldsymbol{x}=\left[\begin{array}{c}x_{1} \\ x_{2} \\ \vdots \\ x_{n}\end{array}\right] \quad \boldsymbol{A}=\left[\begin{array}{cccc}a_{11} & a_{12} & \ldots & a_{1 n} \\ a_{21} & a_{22} & \ldots & a_{2 n} \\ \vdots & \vdots & \ddots & \vdots \\ a_{n 1} & a_{n 2} & \ldots & a_{n n}\end{array}\right] \quad \boldsymbol{y}=\left[\begin{array}{c}y_{1} \\ y_{2} \\ \vdots \\ y_{n}\end{array}\right]$

Matriks $\boldsymbol{A}$ disebut sebagai matriks teknologi. Dengan sedikit modifikasi, persamaan (3) dapat menghasilkan matriks pengganda output sebagai berikut:

$$
\begin{aligned}
& (I-A) x=y \\
& x=(I-A)^{-1} y \\
& x=G y \ldots \ldots \ldots \ldots
\end{aligned}
$$


Matriks $\boldsymbol{G}$ adalah matriks pengganda output atau sering juga disebut sebagai matriks kebalikan Leontief. Kekuatan peramalan dalam model input-output terletak pada matriks $\boldsymbol{G}$ ini. Dengan matriks tersebut kita dapat meramalkan dampak perubahan setiap variabel eksogen dalam permintaan akhir terhadap perubahan output. Angka pengganda output dapat diturunkan sebagai berikut:

$$
O_{j}=\sum_{i=1}^{n} g_{i j}
$$

dengan $O_{j}$ adalah angka pengganda output dari sektor $j$ dan $g_{i j}$ adalah elemen dari matriks $\boldsymbol{G}$.

Angka pengganda output mengukur output total yang tercipta akibat adanya perubahan satu unit permintaan akhir di suatu sektor. Selain angka pengganda output, dapat pula diturunkan angka pengganda Nilai Tambah Bruto (NTB) sebagai berikut:

$$
N T B_{j}=\sum_{i=1}^{n} g_{i j} v_{i}
$$

dengan $N T B_{j}$ adalah angka pengganda NTB dari sektor $j, g_{i j}$ adalah elemen dari matriks $\boldsymbol{G}$, dan $v_{i}$ adalah rasio NTB dari sektor $i$.

Angka pengganda NTB mengukur pendapatan total yang tercipta akibat adanya perubahan satu unit permintaan akhir di suatu sektor.

\section{Keterkaitan Antar Sektor dan Sektor Kunci}

Setiap sektor dalam perekonomian tidak berdiri sendiri, namun terintegrasi. Output dari suatu sektor merupakan input bagi sektor lainnya, begitu pula sebaliknya. Hubungan saling ketergantungan tersebut menciptakan keterkaitan antar sektor. Keterkaitan antar sektor dibagi menjadi dua bagian, yaitu keterkaitan ke belakang (backward linkage) dan keterkaitan ke depan (forward linkage). Ukuran keterkaitan ke belakang pada suatu sektor beranjak dari model Leontief dengan melihat sisi permintaan (demand-driven), sedangkan ukuran keterkaitan ke depan dilihat dari sisi penawaran (supply-driven). Rasmussen (1958) mengajukan ukuran keterkaitan ke belakang dan keterkaitan ke depan sebagai berikut:

$$
\begin{aligned}
& B L_{j}=\sum_{i=1}^{n} g_{i j} . \\
& F L_{i}=\sum_{j=1}^{n} g_{i j} .
\end{aligned}
$$

dengan $B L_{j}$ adalah keterkaitan ke belakang dari sektor $j, F L_{i}$ adalah keterkaitan ke depan dari sektor $i$, dan $g_{i j}$ adalah elemen dari matriks kebalikan Leontief, $\boldsymbol{G}=(\boldsymbol{I}-\boldsymbol{A})^{-\mathbf{1}}$.

Ukuran keterkaitan yang diajukan oleh Rasmussen (1958) lebih baik dibandingkan dengan ukuran keterkaitan Chenery \& Watanabe (1958) karena telah memperhitungkan keterkaitan langsung maupun tidak langsung. Nilai keterkaitan ke belakang $\left(B L_{j}\right)$ berdasarkan ukuran Rasmussen sama dengan angka pengganda output, yaitu merefleksikan pengaruh dari kenaikan permintaan akhir pada sektor $j$ terhadap output perekonomian secara keseluruhan. Sedangkan nilai keterkaitan ke depan $\left(F L_{i}\right)$ merefleksikan besarnya kenaikan output pada sektor $i$ jika pemintaan akhir pada setiap sektor lainnya naik sebanyak satu unit.

Rasmussen (1958) juga memberikan dua jenis ukuran indeks yang disebut kemampuan penyebaran (power of dispersion) dan kepekaan penyebaran (sensitivity of dispersion). Kedua jenis indeks ini dapat digunakan untuk mengidentifikasi sektor kunci dalam pembangunan ekonomi. BPS (1999) memberikan istilah Indeks Daya Penyebaran (IDP) untuk kemampuan penyebaran dan Indeks Derajat Kepekaan (IDK) untuk kepekaan penyebaran. Formula dari masing-masing indeks tersebut adalah sebagai berikut:

$$
\begin{aligned}
& I D P_{j}=\frac{\sum_{i=1}^{n} g_{i j}}{\frac{1}{n} \sum_{i} \sum_{j} g_{i j}} . . \\
& I D K_{i}=\frac{\sum_{j=1}^{n} g_{i j}}{\frac{1}{n} \sum_{i} \sum_{j} g_{i j}} .
\end{aligned}
$$

IDP dan IDK merupakan perbandingan dampak, baik ke belakang maupun ke depan, terhadap rata-rata dampak seluruh sektor. Dengan demikian, nilai IDP > 1 menunjukkan bahwa keterkaitan ke belakang dari sektor tersebut lebih tinggi daripada rata-rata keterkaitan ke belakang seluruh sektor. Begitu pula, nilai IDK $>1$ menunjukkan bahwa keterkaitan ke depan dari sektor tersebut lebih tinggi daripada rata-rata keterkaitan ke depan seluruh sektor. Suatu sektor dengan IDP dan IDK yang lebih besar dari satu dikategorikan sebagai sektor kunci atau sektor unggulan.

\section{Analisis Model IRIO}

Misalkan terdapat tiga daerah dengan $\boldsymbol{A}_{i j}$ adalah matriks teknologi akibat penggunaan input antara pada daerah $j$ dari daerah $i, \boldsymbol{x}_{j}$ adalah vektor output pada daerah $j$, dan $\boldsymbol{y}_{j}$ adalah vektor permintaan akhir pada daerah $j$. Model interregional input-output dari kasus tersebut adalah sebagai berikut (Chen et al., 2020): 
$\left[\begin{array}{lll}\boldsymbol{A}_{11} & \boldsymbol{A}_{12} & \boldsymbol{A}_{13} \\ \boldsymbol{A}_{21} & \boldsymbol{A}_{22} & \boldsymbol{A}_{23} \\ \boldsymbol{A}_{31} & \boldsymbol{A}_{32} & \boldsymbol{A}_{33}\end{array}\right]\left[\begin{array}{l}\boldsymbol{x}_{1} \\ \boldsymbol{x}_{2} \\ \boldsymbol{x}_{3}\end{array}\right]+\left[\begin{array}{l}\boldsymbol{y}_{1} \\ \boldsymbol{y}_{2} \\ \boldsymbol{y}_{3}\end{array}\right]=\left[\begin{array}{l}\boldsymbol{x}_{1} \\ \boldsymbol{x}_{2} \\ \boldsymbol{x}_{3}\end{array}\right]$ berikut:

Jika didefinisikan $\boldsymbol{S}_{j i}=\left(\boldsymbol{I}-\boldsymbol{A}_{j j}\right)^{-1} \boldsymbol{A}_{j i}$, maka total output pada daerah 1 dapat dituliskan sebagai

$$
x_{1}=F_{11} M_{11} y_{1}+F_{11} N_{12} M_{22} y_{2}+F_{11} N_{13} M_{33} y_{3}
$$

dengan $\quad \boldsymbol{F}_{11}=\left[\boldsymbol{I}-\boldsymbol{S}_{12}\left(\boldsymbol{I}-\boldsymbol{S}_{23} \boldsymbol{S}_{32}\right)^{-1}\left(\boldsymbol{S}_{21}+\boldsymbol{S}_{23} \boldsymbol{S}_{31}\right)-\boldsymbol{S}_{13}\left(\boldsymbol{I}-\boldsymbol{S}_{32} \boldsymbol{S}_{23}\right)^{-1}\left(\boldsymbol{S}_{31}+\boldsymbol{S}_{32} \boldsymbol{S}_{21}\right)\right]^{-1}$ adalah feedback effect pada daerah 1 yang disebabkan oleh daerah 2 dan $3, \boldsymbol{M}_{11}=\left(\boldsymbol{I}-\boldsymbol{A}_{11}\right)^{-1}$ adalah matriks pengganda pada daerah $1, \boldsymbol{M}_{22}=\left(\boldsymbol{I}-\boldsymbol{A}_{22}\right)^{-1}$ adalah matriks pengganda pada daerah $2, \boldsymbol{N}_{12}=$ $\boldsymbol{S}_{12}\left(\boldsymbol{I}-\boldsymbol{S}_{23} \boldsymbol{S}_{32}\right)^{-1}+\boldsymbol{S}_{13}\left(\boldsymbol{I}-\boldsymbol{S}_{32} \boldsymbol{S}_{23}\right)^{-1} \boldsymbol{S}_{32}$ adalah efek spillover pada daerah 1 yang berasal dari daerah 2, $\boldsymbol{M}_{33}=\left(\boldsymbol{I}-\boldsymbol{A}_{33}\right)^{-1}$ adalah matriks pengganda pada daerah 3, dan $\boldsymbol{N}_{13}=\boldsymbol{S}_{13}\left(\boldsymbol{I}-\boldsymbol{S}_{32} \boldsymbol{S}_{23}\right)^{-1}+$ $\boldsymbol{S}_{12}\left(\boldsymbol{I}-\boldsymbol{S}_{23} \boldsymbol{S}_{32}\right)^{-1} \boldsymbol{S}_{23}$ adalah efek spillover pada daerah 1 yang berasal dari daerah 3.

Dengan demikian, model interregional input-output pada persamaan (11) dapat ditransformasi menjadi:

$\left[\begin{array}{l}\boldsymbol{x}_{1} \\ \boldsymbol{x}_{2} \\ \boldsymbol{x}_{3}\end{array}\right]=\left[\begin{array}{ccc}\boldsymbol{F}_{11} & 0 & 0 \\ 0 & \boldsymbol{F}_{22} & 0 \\ 0 & 0 & \boldsymbol{F}_{33}\end{array}\right]\left[\begin{array}{ccc}\boldsymbol{I} & \boldsymbol{N}_{12} & \boldsymbol{N}_{13} \\ \boldsymbol{D}_{21} & \boldsymbol{I} & \boldsymbol{D}_{23} \\ \boldsymbol{D}_{31} & \boldsymbol{D}_{32} & \boldsymbol{I}\end{array}\right]\left[\begin{array}{ccc}\boldsymbol{M}_{11} & 0 & 0 \\ 0 & \boldsymbol{M}_{22} & 0 \\ 0 & 0 & \boldsymbol{M}_{33}\end{array}\right]\left[\begin{array}{l}\boldsymbol{y}_{1} \\ \boldsymbol{y}_{2} \\ \boldsymbol{y}_{3}\end{array}\right]$

Matriks kebalikan Leontief dalam model IRIO dapat dinyatakan sebagai berikut:

$$
\boldsymbol{G}=\left[\begin{array}{ccc}
\boldsymbol{F}_{11} \boldsymbol{M}_{11} & \boldsymbol{F}_{11} \boldsymbol{N}_{12} \boldsymbol{M}_{22} & \boldsymbol{F}_{11} \boldsymbol{N}_{13} \boldsymbol{M}_{33} \\
\boldsymbol{F}_{22} \boldsymbol{N}_{21} \boldsymbol{M}_{11} & \boldsymbol{F}_{22} \boldsymbol{M}_{22} & \boldsymbol{F}_{22} \boldsymbol{N}_{23} \boldsymbol{M}_{33} \\
\boldsymbol{F}_{33} \boldsymbol{N}_{31} \boldsymbol{M}_{11} & \boldsymbol{F}_{33} \boldsymbol{N}_{32} \boldsymbol{M}_{22} & \boldsymbol{F}_{33} \boldsymbol{M}_{33}
\end{array}\right]
$$

Model di atas memiliki makna bahwa dampak perubahan output akibat shock permintaan akhir regional dapat didekomposisikan menjadi perkalian dari dampak pengganda regional, efek spillover regional, dan feedback effect.

\section{HASIL DAN PEMBAHASAN}

\section{Gambaran Umum Perekonomian Bali}

Tabel 1 menyajikan neraca penyediaan dan penggunaan barang dan jasa dalam perekonomian Bali. Dari tabel tersebut bisa diperoleh informasi mengenai asal barang dan jasa di Bali serta alokasi penggunaannya. Produk barang dan jasa di Provinsi Bali utamanya berasal dari output domestik sebesar $72.58 \%$. Produk yang berasal dari provinsi lain juga cukup besar, yaitu sebesar $23.34 \%$. Sisanya berasal dari impor luar negeri sebesar $4.08 \%$. Produk yang tersedia umumnya digunakan untuk input proses produksi (permintaan antara: $32.60 \%)$, konsumsi rumah tangga (21.86\%), dan Pembentukan Modal Tetap Bruto (14.32\%). Provinsi Bali juga memiliki porsi ekspor yang cukup besar, baik ekspor antar provinsi (11.56\%) maupun ekspor luar negeri (14.80\%). Ekspor tersebut utamanya berasal dari penyediaan akomodasi dan makan minum.

\begin{tabular}{|c|c|c|c|c|c|}
\hline \multicolumn{3}{|c|}{ Penggunaan } & \multicolumn{3}{|c|}{ Sumber } \\
\hline Deskripsi & Nilai & $\%$ & Deskripsi & Nilai & $\%$ \\
\hline Permintaan Antara & $157,220,545$ & 32.60 & Output Domestik & $350,047,054$ & 72.58 \\
\hline Konsumsi Rumah Tangga & $105,441,154$ & 21.86 & Impor Antar Provinsi & $112,572,707$ & 23.34 \\
\hline Konsumsi LNPRT & $2,407,213$ & 0.50 & Impor Luar Negeri & $19,694,604$ & 4.08 \\
\hline Konsumsi Pemerintah & $19,887,252$ & 4.12 & & & \\
\hline PMTB & $69,063,353$ & 14.32 & & & \\
\hline Perubahan Inventori & $1,162,800$ & 0.24 & & & \\
\hline Ekspor Antar Provinsi & $55,766,700$ & 11.56 & & & \\
\hline Ekspor Luar Negeri & $71,365,349$ & 14.80 & & & \\
\hline Total & $482,314,365$ & 100.00 & Total & $482,314,365$ & 100.00 \\
\hline
\end{tabular}

Tabel 1. Neraca barang dan jasa dari perekonomian Bali.

Perekonomian Bali utamanya ditopang oleh sektor pariwisata dan pertanian. Beberapa sektor pariwisata seperti Penyediaan Akomodasi \& Makan Minum, Perdagangan, dan Transportasi \& Pergudangan berkontribusi sebesar $42.08 \%$ terhadap perekonomian Bali. Pertanian, Kehutanan \& Perikanan juga memiliki kontribusi yang cukup besar, yaitu sebesar 9.63\%. Porsi sektor-sektor energi seperti Pertambangan \& Penggalian, Pengadaan Air, serta Listrik \& Gas belum cukup besar di Provinsi Bali. Ketiga lapangan usaha tersebut hanya berkontribusi sebesar 1.6\% terhadap perekonomian Bali (Gambar 1). 


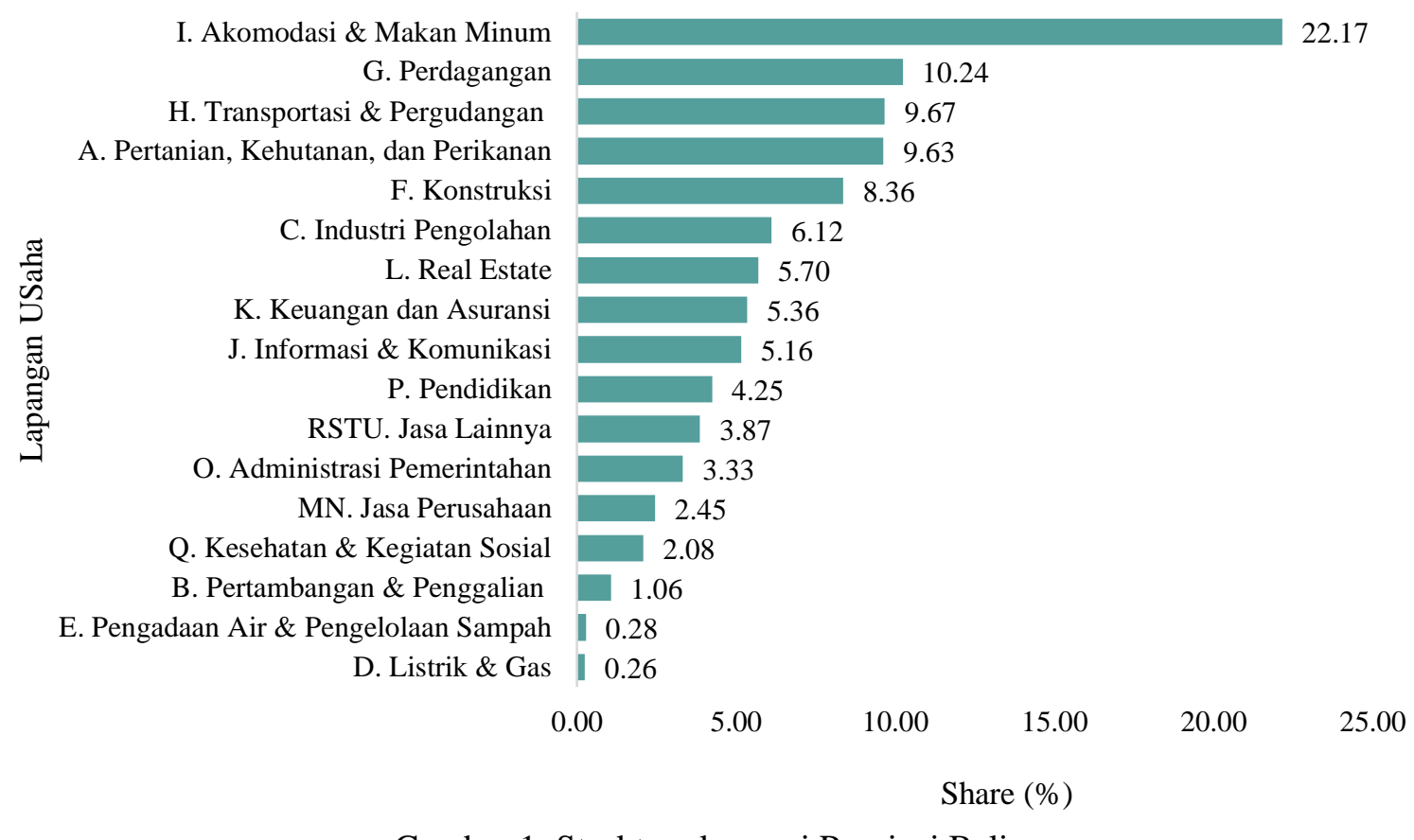

\section{Gambar 1. Struktur ekonomi Provinsi Bali.}

Gambar 2 menyajikan rasio Nilai Tambah Bruto (NTB) untuk masing-masing lapangan usaha di Provinsi Bali. Lapangan usaha Keuangan \& Asuransi memiliki rasio NTB terbesar, yaitu sebesar 0.81. Artinya, dari $100 \%$ output lapangan usaha Keuangan \& Asuransi dapat menciptakan $81 \%$ pendapatan primer, baik dalam bentuk upah dan gaji bagi pekerja, pajak bagi pemerintah, dan surplus usaha bagi perusahaan. Rasio NTB untuk lapangan usaha Real Estate, Pertanian, Kehutanan \& Perikanan, dan Jasa Pendidikan juga cukup besar, yaitu masing-masing sebesar $0.76,0.75$ dan 0.71 . Lapangan usaha Listrik \& Gas memiliki rasio NTB yang paling kecil, yaitu hanya sebesar 0.06 . Dari $100 \%$ output lapangan usaha Listrik \& Gas hanya menciptakan sebesar $6 \%$ pendapatan primer.

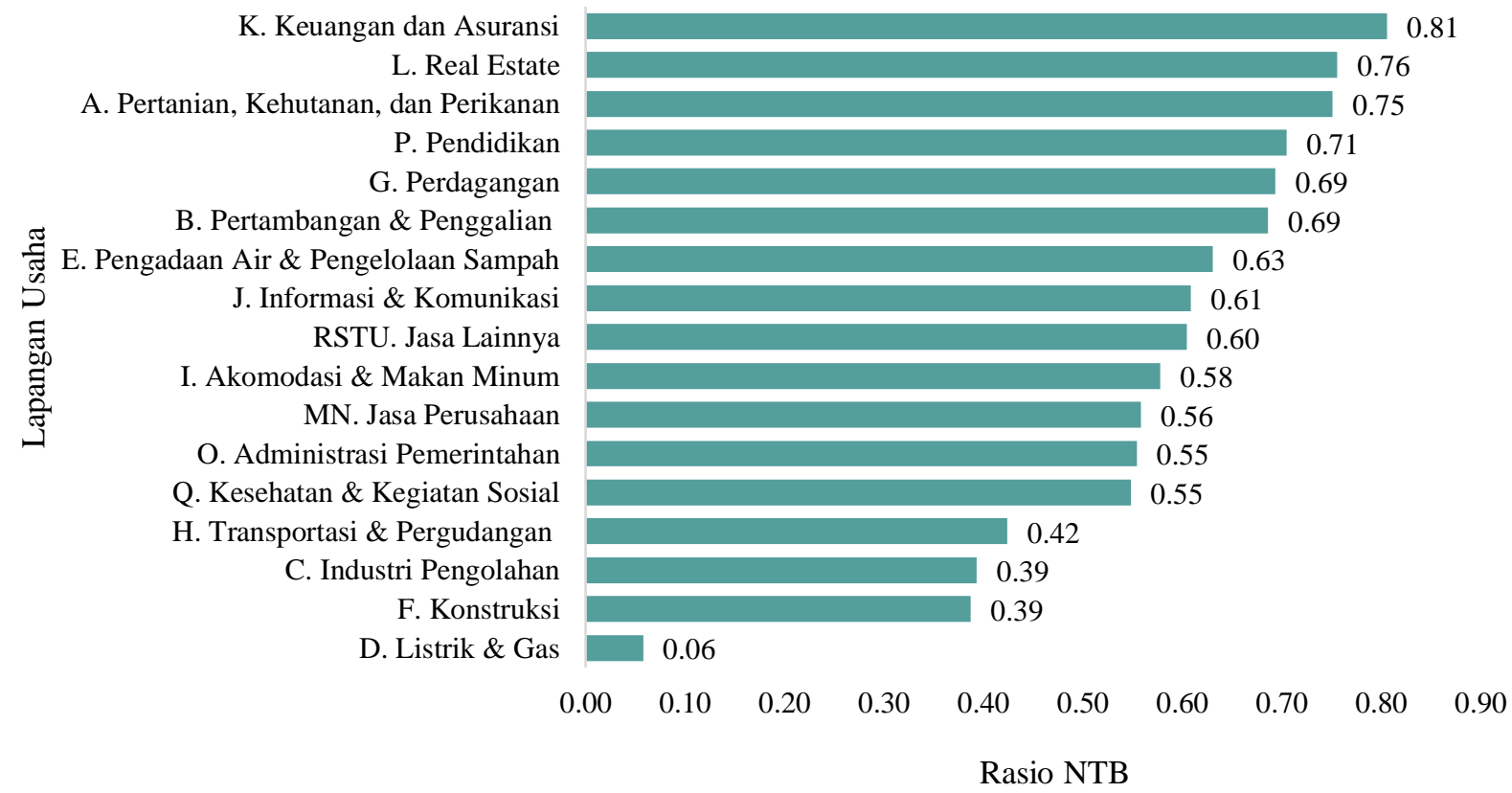

Gambar 2. Rasio Nilai Tambah Bruto (NTB) masing-masing lapangan usaha di Provinsi Bali.

Gambar 3 menunjukkan destinasi ekspor Provinsi Bali. Lebih dari separuh (58.77\%) ekspor Bali merupakan ekspor luar negeri. Hal ini tidak terlepas dari peran Bali sebagai pilar pariwisata nasional yang menjadi destinasi favorit bagi wisatawan mancanegara. Ekspor Bali juga bergantung pada daerah-daerah di Pulau Jawa seperti DKI Jakarta (8.88\%), Jawa Barat (6.00\%), Jawa Timur (3.60\%), Banten (2.89\%) dan Jawa Tengah (2.63\%). Ekspor Bali ke DKI Jakarta, Jawa Barat dan Jawa Tengah umumnya dalam bentuk jasa 
transportasi, sedangkan ekspor Bali ke Jawa Timur umumnya dalam bentuk perdagangan dan hasil-hasil pertanian. Disamping itu, ekspor Bali juga banyak ke Provinsi Nusa Tenggara Barat, yaitu sebesar $2.41 \%$. Ekspor Bali ke Nusa Tenggara Barat utamanya berasal dari sektor Industri Pengolahan.

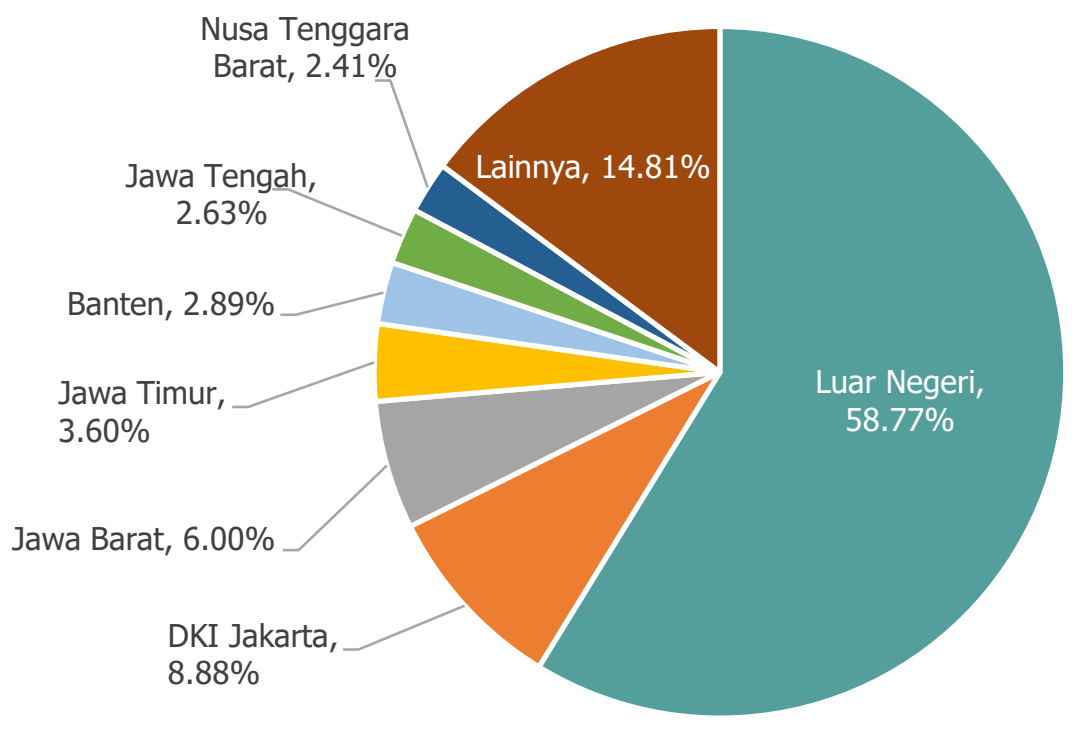

Gambar 3. Destinasi ekspor Provinsi Bali.

Gambar 4 menyajikan asal impor Provinsi Bali. Impor Bali utamanya bergantung pada daerah-daerah di Pulau Jawa, seperti Jawa Timur (23.21\%), DKI Jakarta (14.12\%), Banten (9.10\%), Jawa Tengah (8.34\%) dan Jawa Barat (7.73\%). Impor Bali dari Pulau Jawa mencakup 62.5\% dari total impor Bali. Impor Bali dari Pulau Jawa umumnya berbentuk hasil-hasil industri pengolahan dan perdagangan. Impor Bali dari provinsi Sulawesi Selatan dan Sumatera Selatan juga cukup besar, yaitu masing-masing sebesar 6.60\% dan 5.11\%. Impor Bali dari luar negeri mencakup $11.06 \%$ dari total impor Bali.

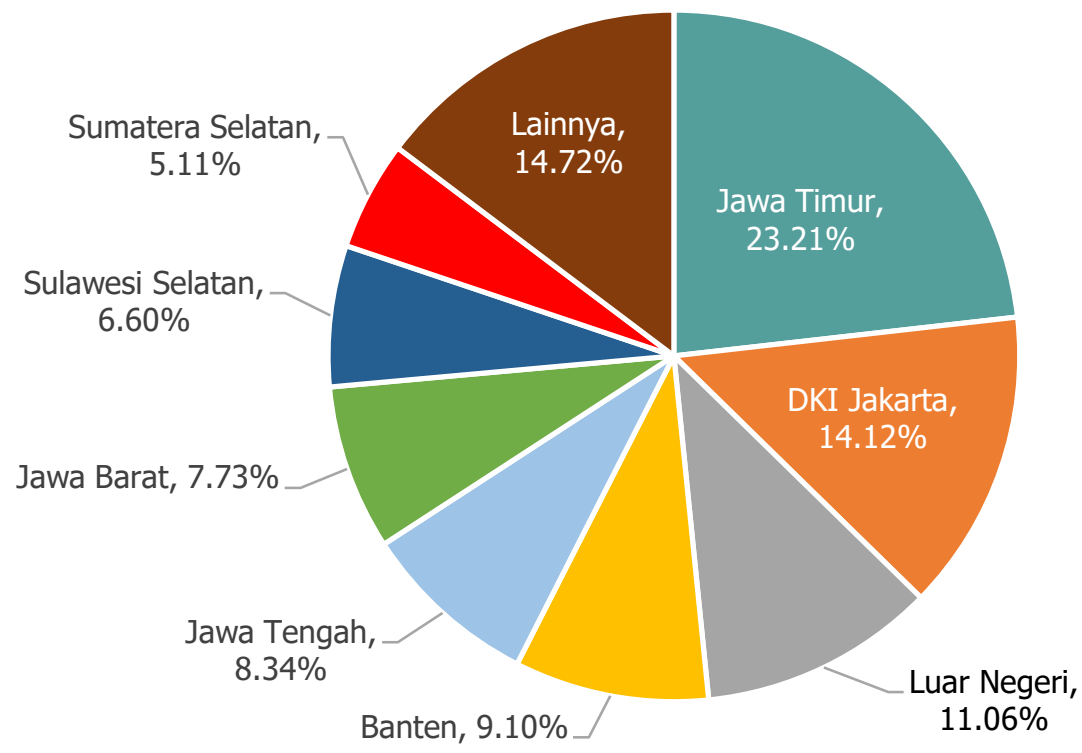

Gambar 4. Daerah asal impor Provinsi Bali.

Impor provinsi Bali untuk keperluan proses produksi (input antara) dapat dibagi menurut lapangan usaha pada Tabel 2. Lapangan usaha di Bali umumnya masih bergantung pada output domestik. Namun, beberapa lapangan usaha seperti Pertambangan \& Penggalian serta Jasa Kesehatan \& Kegiatan Sosial lebih banyak bergantung pada impor dari provinsi lain untuk keperluan proses produksinya. 
Tabel 2. Sumber input antara masing-masing lapangan usaha di Provinsi Bali.

\begin{tabular}{|c|c|c|c|c|c|}
\hline \multirow[b]{2}{*}{$\begin{array}{c}\text { Kategori } \\
\text { Lapangan } \\
\text { Usaha }\end{array}$} & \multirow[b]{2}{*}{ Deskripsi } & \multicolumn{4}{|c|}{ Sumber Input Antara (\%) } \\
\hline & & Domestik & $\begin{array}{l}\text { Impor dari } \\
\text { Luar } \\
\text { Negeri }\end{array}$ & $\begin{array}{l}\text { Impor dari } \\
\text { Provinsi } \\
\text { Lain }\end{array}$ & Total \\
\hline A & Pertanian, Kehutanan, dan Perikanan & 52.57 & 0.85 & 46.58 & 100.00 \\
\hline B & Pertambangan dan Penggalian & 44.66 & 2.60 & 52.74 & 100.00 \\
\hline $\mathrm{C}$ & Industri Pengolahan & 58.27 & 5.06 & 36.68 & 100.00 \\
\hline $\mathrm{D}$ & Pengadaan Listrik dan Gas & 70.07 & 0.90 & 29.03 & 100.00 \\
\hline $\mathrm{E}$ & $\begin{array}{c}\text { Pengadaan Air, Pengelolaan Sampah, } \\
\text { Limbah dan Daur Ulang }\end{array}$ & 57.18 & 3.93 & 38.89 & 100.00 \\
\hline $\mathrm{F}$ & Konstruksi & 49.83 & 4.76 & 45.42 & 100.00 \\
\hline G & $\begin{array}{c}\text { Perdagangan Besar dan Eceran; Reparasi } \\
\text { Mobil dan Sepeda Motor }\end{array}$ & 71.85 & 3.84 & 24.31 & 100.00 \\
\hline $\mathrm{H}$ & Transportasi dan Pergudangan & 52.38 & 4.16 & 43.45 & 100.00 \\
\hline I & Penyediaan Akomodasi dan Makan Minum & 56.72 & 1.36 & 41.91 & 100.00 \\
\hline $\mathrm{J}$ & Informasi dan Komunikasi & 82.14 & 2.70 & 15.15 & 100.00 \\
\hline K & Jasa Keuangan dan Asuransi & 76.70 & 2.81 & 20.48 & 100.00 \\
\hline $\mathrm{L}$ & Real Estate & 88.97 & 1.30 & 9.72 & 100.00 \\
\hline $\mathrm{MN}$ & Jasa Perusahaan & 76.24 & 7.16 & 16.60 & 100.00 \\
\hline $\mathrm{O}$ & $\begin{array}{l}\text { Administrasi Pemerintahan, Pertahanan dan } \\
\text { Jaminan Sosial Wajib }\end{array}$ & 70.56 & 6.51 & 22.93 & 100.00 \\
\hline $\mathrm{P}$ & Jasa Pendidikan & 66.05 & 7.43 & 26.52 & 100.00 \\
\hline Q & Jasa Kesehatan dan Kegiatan Sosial & 45.45 & 2.53 & 52.01 & 100.00 \\
\hline RSTU & Jasa Lainnya & 67.82 & 3.44 & 28.74 & 100.00 \\
\hline
\end{tabular}

\section{Analisis Keterkaitan Antar Sektor}

Tabel 3 berisi matriks keterkaitan antar sektor di Provinsi Bali. Semakin hijau warna sel, semakin tinggi keterkaitan antar sektor. Warna kuning menunjukkan keterkaitan antar sektor yang moderat, sedangkan warna merah menunjukkan keterkaitan antar sektor yang rendah. Analisis secara kolom menunjukkan seberapa besar shock permintaan akhir di sektor tersebut berdampak pada output sektor lainnya. Sedangkan analisis secara baris menunjukkan seberapa besar respon output di sektor tersebut terhadap shock permintaan akhir di sektor lainnya. Sektor Pertambangan \& Penggalian (B), Pengadaan Air \& Pengelolaan Sampah (E), Administrasi Pemerintahan (O), Jasa Pendidikan (P) dan Jasa Kesehatan \& Kegiatan Sosial (Q) umumnya memiliki respon perubahan output yang rendah ketika terjadi shock permintaan akhir di sektor lainnya. Sektor Penyediaan Akomodasi \& Makan Minum (I) sebagai sektor dengan kontribusi terbesar di Provinsi Bali memiliki dampak output yang moderat terhadap sektor lainnya. Misalnya, jika permintaan akhir di sektor Penyediaan Akomodasi \& Makan Minum (I) meningkat sebesar Rp 1000, maka output di sektor Pertanian, Kehutanan \& Perikanan meningkat sebesar Rp 85.9. Hal ini dapat terjadi karena sektor Penyediaan Akomodasi \& Makan Minum (I) bergantung pada hasil-hasil pertanian sebagai inputnya.

Tabel 3. Keterkaitan antar sektor di Provinsi Bali.

\begin{tabular}{|c|c|c|c|c|c|c|c|c|c|c|c|c|c|c|c|c|c|}
\hline Kode & A & B & C & D & $\mathrm{E}$ & $F$ & G & $\mathrm{H}$ & I & J & $K$ & L & MN & 0 & $\mathbf{P}$ & $\mathbf{Q}$ & RSTU \\
\hline A & 1.0776 & 0021 & 1826 & 0.0022 & 0.0031 & 0217 & 0029 & 0.0075 & 0.0859 & 0029 & 0018 & 0029 & 0.0094 & .0173 & 0091 & 0288 & 0.0155 \\
\hline B & & & & & & & & & & & & & & & & .0005 & 007 \\
\hline C & 0.0189 & & & & & & & & & & & & & & & & \\
\hline D & 0.0216 & 0.0080 & 0.0291 & 94 & .07 & & & & & & & & & & & & \\
\hline E & 0.0001 & 0.0004 & 0.0002 & 0.0004 & 1.0334 & 0.0001 & & & & & & & & & & & 022 \\
\hline $\mathbf{F}$ & 0.0021 & 0.0015 & 0.0035 & 0.0015 & 0.0065 & 1.0207 & 0.0051 & 0.0032 & 0.0029 & 0.0031 & 0.0107 & 0.0822 & & & 62 & 31 & 0.0082 \\
\hline G & 0.0274 & 0.0392 & 0.0645 & 0.0307 & 0.0280 & 0.0734 & & 0.0471 & 0.0424 & & & 0.0094 & & & 0.0167 & & \\
\hline H & 0.0083 & 0.0351 & 0.0326 & & 0.0277 & & & & & & & & & & & & \\
\hline I & & 9 & 3 & & & & 0 & 0.0 & 22 & 6 & 6 & 96 & & & 46 & 81 & 78 \\
\hline J & 37 & 0174 & 26 & 22 & 54 & 5 & 95 & 61 & 0 & 4 & 326 & 84 & 34 & 50 & 02 & 22 & $0 . C$ \\
\hline K & 056 & 0069 & 79 & 72 & 59 & 9 & 1 & 6 & 4 & & 18 & 77 & 27 & 75 & 50 & 22 & 63 \\
\hline L & 0. & 0 & & & & & & & & & & & & & & & \\
\hline MN & 0.0026 & 0.0228 & 0.0127 & 0.0651 & 0.0249 & 0.0294 & 0.0242 & 0.0341 & 0.0156 & 0.0501 & 0.0365 & 0.0388 & 1.0477 & 0.0419 & 0.0301 & 0.0139 & 0.0422 \\
\hline 0 & 0.0001 & 0.0004 & 0.0003 & 0.0036 & 0.0106 & 0.0004 & 0.0008 & 0.0016 & 0.0006 & 0.0099 & 0.0027 & 0.0043 & 0.0017 & 1.0032 & 0.0013 & 0.0018 & 0.0007 \\
\hline $\mathbf{p}$ & 0.0001 & 0.0002 & 0.0003 & 0.0007 & 0.0047 & 0.0003 & 0.0008 & 0.0026 & 0.0009 & 0.0020 & 0.0047 & 0.0005 & 0.0009 & 0.0038 & 1.0170 & 0.0028 & 0.0022 \\
\hline $\mathbf{Q}$ & 0.0000 & 0.0001 & 0.0002 & 0.0001 & 0.0001 & 0.0001 & 0.0004 & 0.0008 & 0.0002 & 0.0002 & 0.0006 & 0.0004 & 0.0003 & 0.0003 & 0.0023 & 1.0065 & 0.0039 \\
\hline RSTU & 0.0031 & 0.0023 & 0.0049 & 0.0018 & 0.0107 & 0.0050 & 0.0051 & 0.0198 & 0.0072 & 0.0301 & 0.0018 & 0.0023 & 0.0111 & 0.0066 & 0.0029 & 0.0074 & 1.0227 \\
\hline
\end{tabular}

Besarnya pengganda output dan pengganda Nilai Tambah Bruto (NTB) masing-masing lapangan usaha di Bali terhadap perekonomian Bali disajikan dalam Gambar 5. Sedangkan besarnya pengganda output dan 
pengganda NTB masing-masing lapangan usaha di Bali terhadap total perekonomian Indonesia disajikan dalam Gambar 6. Listrik \& Gas (D) memiliki dampak output yang paling besar, baik bagi perekonomian Bali maupun bagi perekonomian nasional. Jika permintaan akhir lapangan usaha Listrik \& Gas (D) di Bali meningkat sebesar Rp 1000, maka output total di Bali meningkat sebesar Rp 2600 dan output total Indonesia meningkat sebesar Rp 4190. Namun, yang menarik adalah dampak pengganda NTB dari lapangan usaha Listrik \& Gas (D) di Bali paling rendah dibandingkan dengan lapangan usaha lainnya. Hal ini terjadi karena rasio NTB Listrik \& Gas (D) di Bali hanya sebesar 0.06 (lih. Gambar 2). Jika permintaan akhir lapangan usaha Listrik \& Gas (D) di Bali meningkat sebesar Rp 1000, maka NTB total di Bali meningkat sebesar Rp 320 dan NTB total Indonesia meningkat sebesar Rp 900.

- Pengganda Output $\quad$ Pengganda NTB

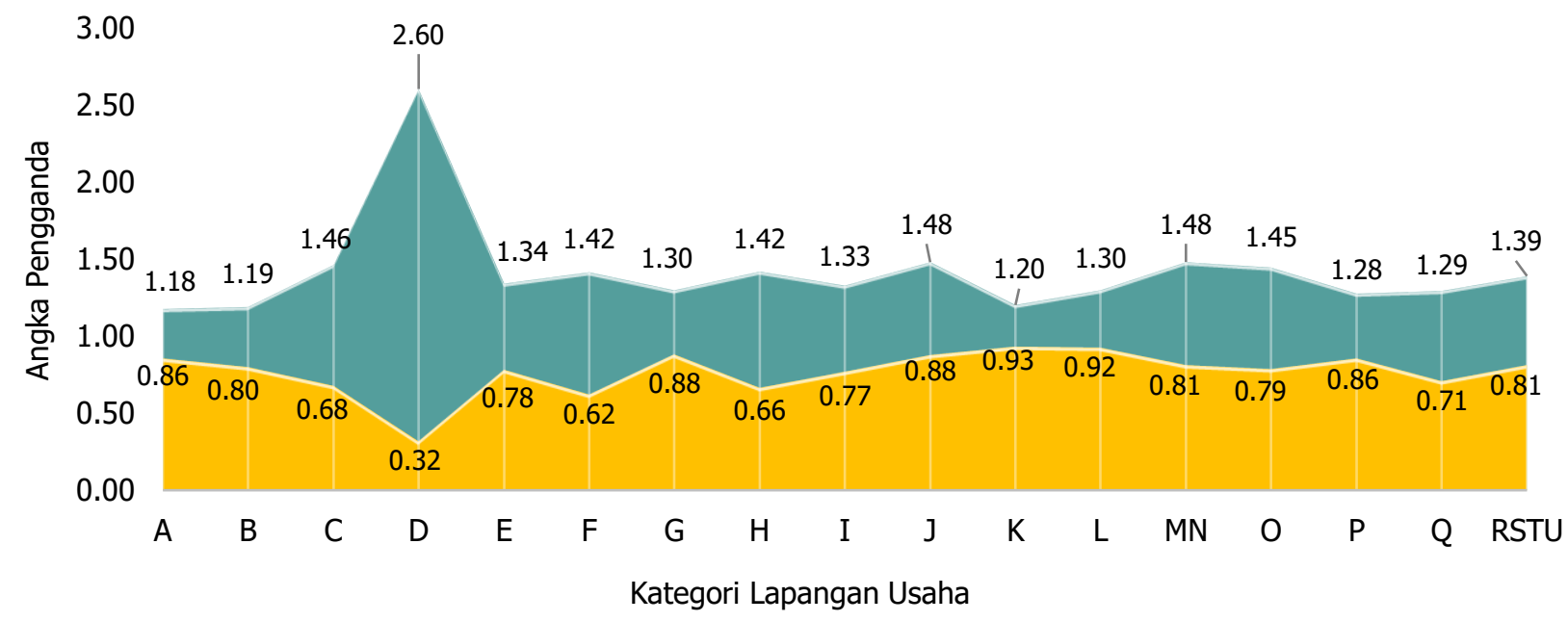

Gambar 5. Pengganda output dan pengganda Nilai Tambah Bruto (NTB) masing-masing lapangan usaha di Bali terhadap total perekonomian Bali.

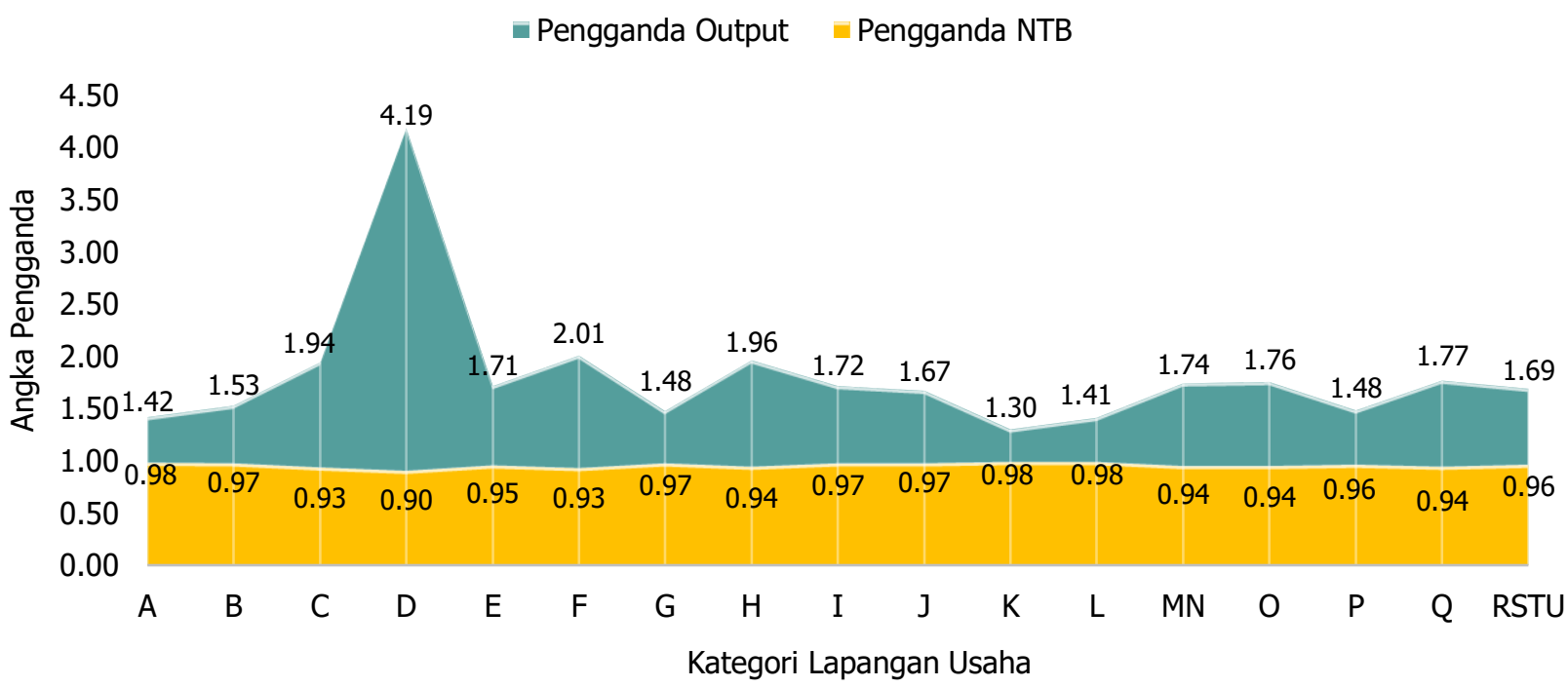

Gambar 6. Pengganda output dan pengganda Nilai Tambah Bruto (NTB) masing-masing lapangan usaha di Bali terhadap total perekonomian nasional.

Gambar 7 menyajikan pengganda tenaga kerja masing-masing lapangan usaha di Bali. Pengganda tenaga kerja terbesar dihasilkan oleh lapangan usaha Pertanian, Kehutanan dan Perikanan (A). Jika permintaan akhir untuk Pertanian, Kehutanan dan Perikanan (A) meningkat sebesar 1 milyar rupiah, jumlah tenaga kerja yang diserap di Bali meningkat sekitar 23 orang. Pengganda tenaga kerja untuk Industri Pengolahan (C) dan Perdagangan (G) juga cukup besar, yaitu masing-masing sebesar 19.29 dan 17.90. Jika permintaan akhir untuk Industri Pengolahan (C) meningkat sebesar 1 milyar rupiah, jumlah tenaga kerja yang diserap di Bali meningkat sekitar 20 orang, sedangkan jika permintaan akhir untuk Perdagangan (G) meningkat sebesar 1 milyar rupiah, jumlah tenaga kerja yang diserap di Bali meningkat sekitar 18 orang. Lapangan usaha Listrik 
\& Gas (D) yang memiliki pengganda output terbesar, justru memiliki pengganda tenaga kerja yang relatif kecil dibandingkan dengan lapangan usaha lainnya.

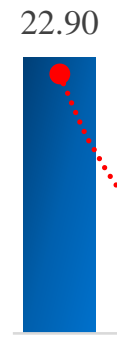

A

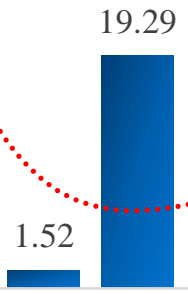

C D

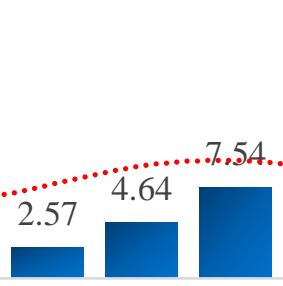

E $\quad \mathrm{F}$
17.90
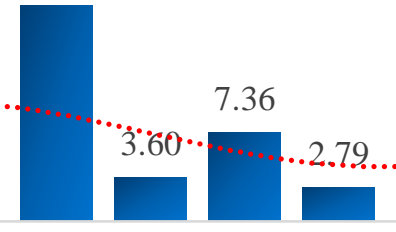

G

Kode Lapangan Usaha

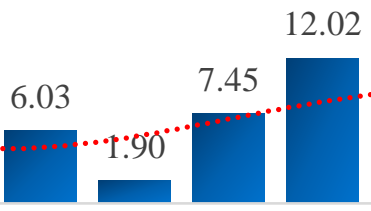

K $\quad$ L $\quad$ MN $\quad$ O $\quad$ P
12.60

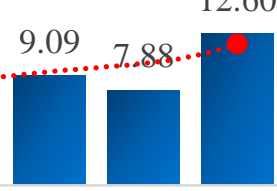

Q RSTU

Gambar 7. Pengganda tenaga kerja masing-masing lapangan usaha di Bali.

Keterkaitan antar sektor, baik keterkaitan ke belakang (backward linkage) maupun keterkaitan ke depan (forward linkage) dapat digunakan untuk mengidentifikasi sektor kunci atau industri unggulan. Analisis tersebut dapat dihasilkan melalui ukuran Indeks Daya Penyebaran (IDP) dan Indeks Derajat Kepekaan (IDK). Tabel 4 menyajikan daftar industri unggulan di Provinsi Bali menurut klasifikasi 52 industri. Industri unggulan di Provinsi Bali umumnya merupakan industri-industri pariwisata dan penunjangnya, seperti Penyediaan Akomodasi, Penyediaan Makan Minum, Angkutan Udara, Perdagangan, Industri Kayu dan Barang dari Kayu (barang-barang kerajinan dari kayu), Real Estate (kawasan pariwisata), Jasa Perusahaan (agen perjalanan, penyelenggaraan tur dan jasa reservasi), dan Jasa Lainnya (aktivitas kesenian, hiburan, rekreasi, spa). Industri unggulan di Provinsi Bali juga termasuk Ketenagalistrikan dan Informasi \& Komunikasi.

Tabel 4. Industri Unggulan di Provinsi Bali.

\begin{tabular}{cccc}
\hline Kode Industri & Deskripsi & IDP & IDK \\
\hline I-28 & Ketenagalistrikan & 2.01 & 2.81 \\
I-33 & Perdagangan Besar dan Eceran, Bukan Mobil dan Sepeda & 1.02 & 1.95 \\
I-42 & Motor & 1.14 & 1.72 \\
I-48 & Jasa Informasi dan Komunikasi & 1.14 & 1.51 \\
I-41 & Jasa Perusahaan & 1.06 & 1.26 \\
I-38 & Penyediaan Makan Minum & 1.13 & 1.26 \\
I-17 & Angkutan Udara & 1.12 & 1.23 \\
I-47 & Industri Kayu dan Barang dari Kayu & 1.00 & 1.22 \\
I-52 & Real Estate & 1.07 & 1.02 \\
I-40 & Jasa Lainnya & 1.01 & 1.01 \\
\hline
\end{tabular}

\section{Analisis Keterkaitan dengan Provinsi Lain}

Perubahan perekonomian di Provinsi Bali tidak hanya berdampak bagi Bali sendiri, namun juga berdampak pada perekonomian provinsi lain. Gambar 8 dan Gambar 9 mengilustrasikan bagaimana shock permintaan akhir di Provinsi Bali berdampak pada output dan Nilai Tambah Bruto (NTB) di provinsi lainnya.

Shock permintaan akhir di Provinsi Bali memiliki dampak output dan NTB yang besar ke provinsiprovinsi di Pulau Jawa, Provinsi Sumatera Selatan dan Provinsi Sulawesi Selatan. Dampak output dan NTB yang paling besar dirasakan oleh Provinsi Jawa Timur, dengan angka pengganda output dan NTB (dalam ribu rupiah) masing-masing sebesar 77.82 dan 43.06. Artinya, jika permintaan akhir di Provinsi Bali meningkat sebesar Rp 1000, maka output dan NTB di Provinsi Jawa Timur masing-masing meningkat sebesar Rp 77.82 dan Rp 43.06. Hal ini tidak terlepas dari sumber impor Bali yang utamanya berasal dari Jawa Timur. Provinsi Bali utamanya bergantung pada hasil-hasil Industri Pengolahan dari Provinsi Jawa Timur. 


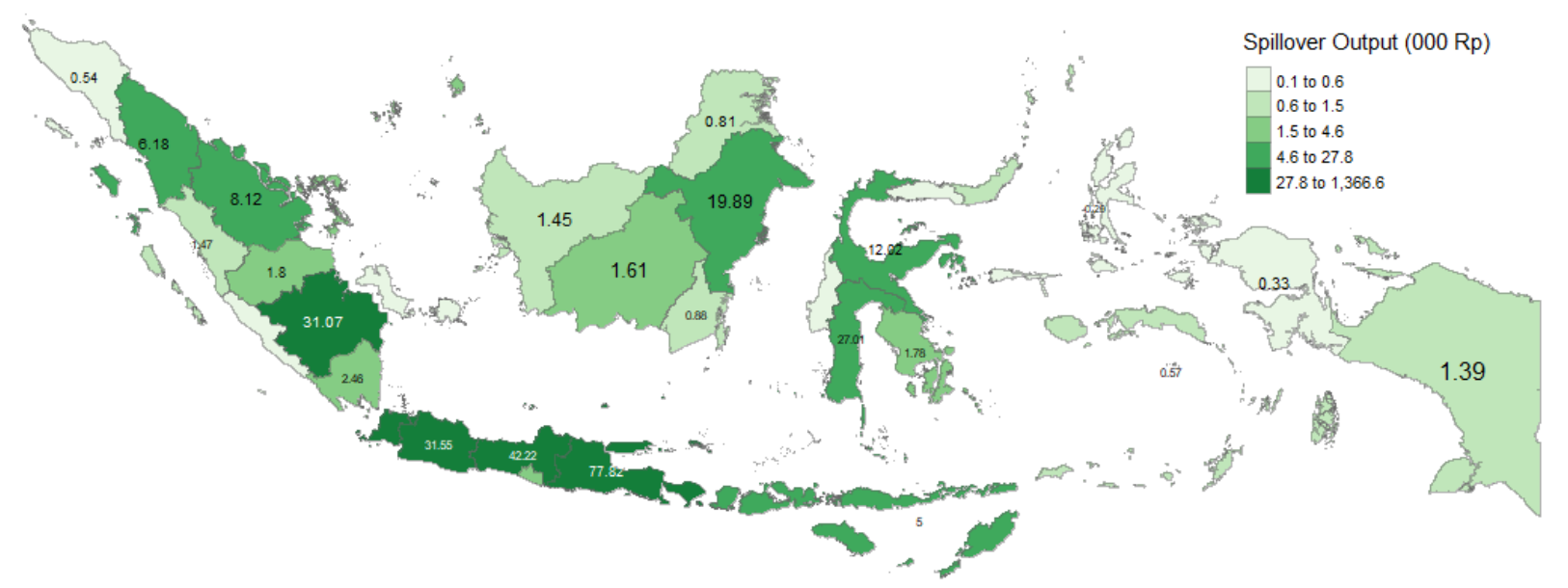

Gambar 8. Dampak output ke provinsi lain akibat shock permintaan akhir di Provinsi Bali (000 Rp).

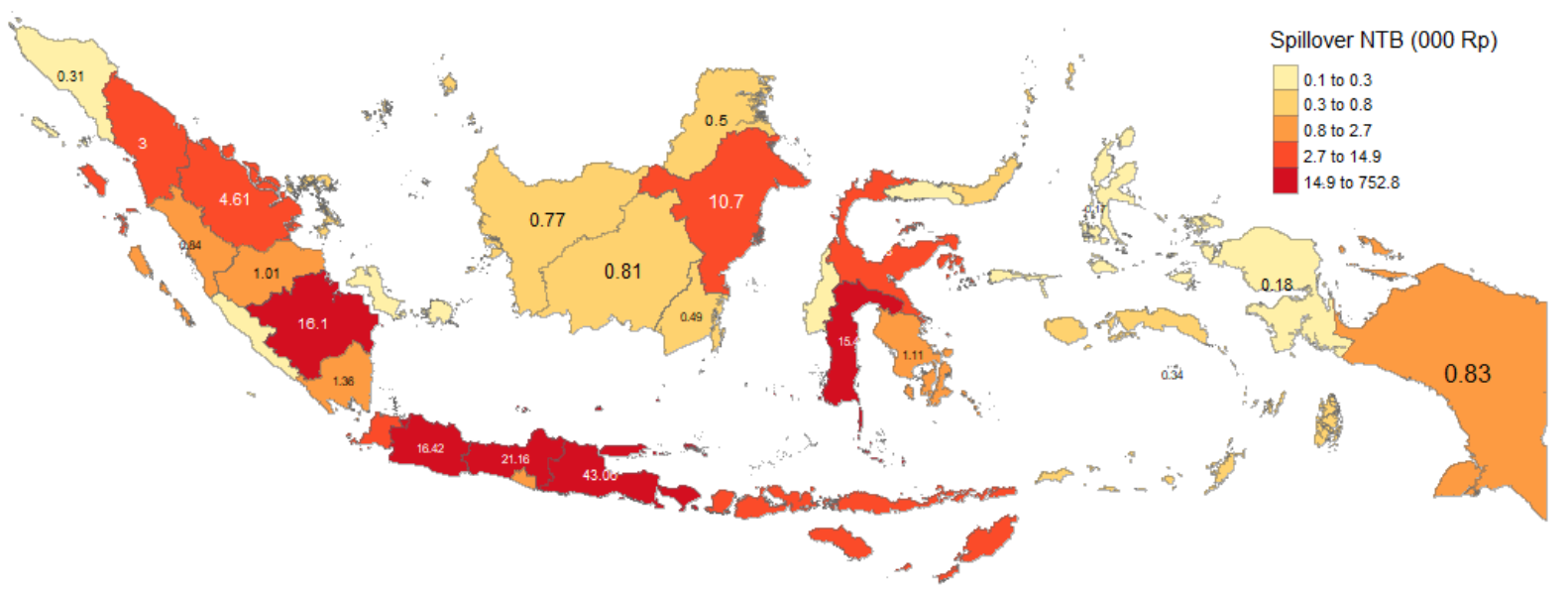

Gambar 9. Dampak Nilai Tambah Bruto (NTB) ke provinsi lain akibat shock permintaan akhir di Provinsi Bali (000 Rp).

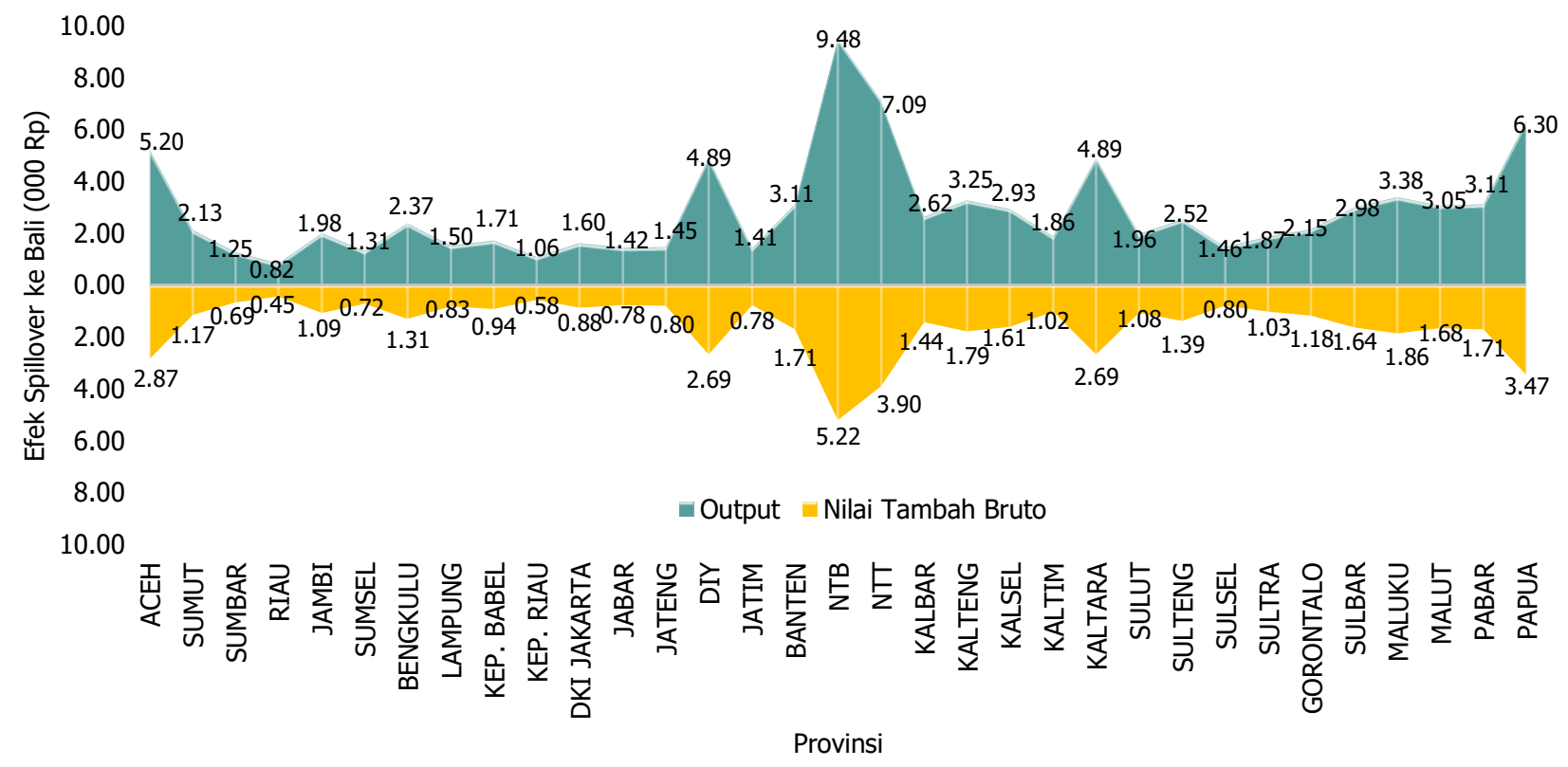

Gambar 10. Dampak output dan Nilai Tambah Bruto ke provinsi Bali akibat shock permintaan akhir di provinsi lain (000 Rp).

Perubahan perekonomian di Provinsi Bali dapat juga diakibatkan oleh shock permintaan akhir di provinsi lainnya. Gambar 10 menampilkan dampak output dan Nilai Tambah Bruto ke provinsi Bali akibat shock permintaan akhir di provinsi lainnya (dalam ribuan rupiah). Dampak output dan Nilai Tambah Bruto paling 
besar ke Bali terjadi ketika ada shock permintaan akhir di Provinsi Nusa Tenggara Barat (NTB). Jika permintaan akhir di Provinsi Nusa Tenggara Barat meningkat sebesar Rp 1000, maka output dan Nilai Tambah Bruto di Provinsi Bali masing-masing meningkat sebesar Rp 9.48 dan Rp 5.22. Hal yang menarik adalah output dan Nilai Tambah Bruto di Bali juga terpengaruh oleh shock permintaan akhir di provinsi-provinsi yang jaraknya relatif jauh dari Bali, seperti Aceh, Papua, dan Kalimantan Utara (Kaltara). Jika permintaan akhir di Provinsi Aceh meningkat sebesar Rp 1000, maka output dan Nilai Tambah Bruto di Provinsi Bali masingmasing meningkat sebesar Rp 5.20 dan Rp 2.87. Jika permintaan akhir di Provinsi Papua meningkat sebesar Rp 1000, maka output dan Nilai Tambah Bruto di Provinsi Bali masing-masing meningkat sebesar Rp 6.30 dan Rp 3.47. Selanjutnya, jika permintaan akhir di Provinsi Kalimantan Utara meningkat sebesar Rp 1000, maka output dan Nilai Tambah Bruto di Provinsi Bali masing-masing meningkat sebesar Rp 4.89 dan Rp 2.69. Hal ini disebabkan oleh porsi input antara yang diimpor dari Bali pada masing-masing provinsi tersebut (Aceh, Papua dan Kalimantan Utara) relatif lebih besar dibandingkan dengan provinsi-provinsi lainnya (Gambar 11).

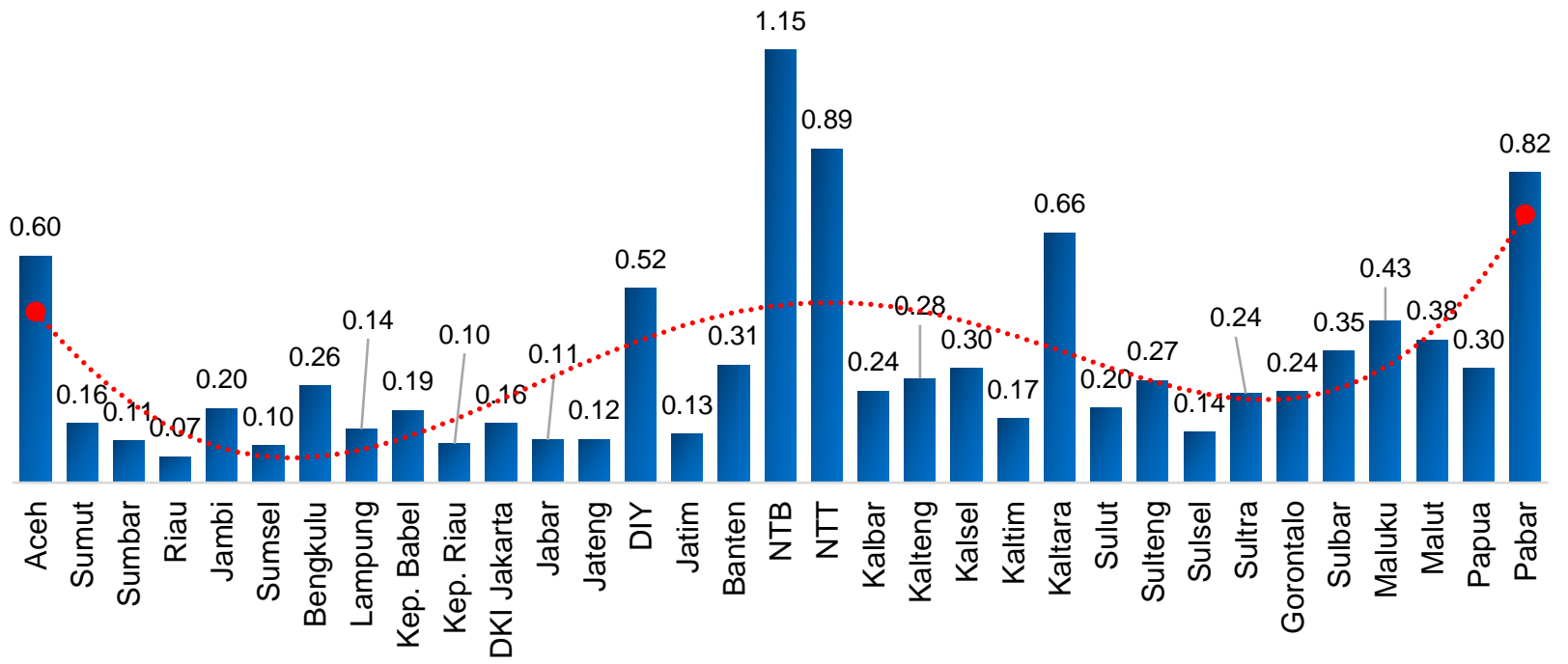

Gambar 11. Porsi input antara yang diimpor dari Bali pada masing-masing provinsi (\%).

\section{KESIMPULAN}

Industri unggulan di Provinsi Bali terdiri atas Penyediaan Akomodasi, Penyediaan Makan Minum, Angkutan Udara, Perdagangan, Industri Kayu dan Barang dari Kayu, Real Estate, Jasa Perusahaan, Jasa Lainnya, Ketenagalistrikan dan Informasi \& Komunikasi. Industri Listrik \& Gas (D) memiliki keterkaitan ke depan dan keterkaitan ke belakang yang sangat tinggi dibandingkan dengan industri-industri lainnya. Shock permintaan akhir sebesar Rp 1000 di industri Listrik \& Gas (D) berdampak pada peningkatan output Provinsi Bali sebesar Rp 2600 dan peningkatan output nasional sebesar Rp 4190. Jika dilihat berdasarkan daerah, shock permintaan akhir di Provinsi Bali memiliki dampak ekonomi yang paling besar terhadap provinsi-provinsi di Pulau Jawa, khususnya Provinsi Jawa Timur. Terakhir, perekonomian di Provinsi Bali sangat dipengaruhi oleh shock permintaan akhir di Provinsi Nusa Tenggara Barat.

\section{DAFTAR PUSTAKA}

Antara, M. (2000). Dampak Pengeluaran Pemerintah dan Wisatawan serta Investasi Swasta terhadap Kinerja Perekonomian Bali: Suatu Simulasi Model Social Accounting Matrix. SOCA: Jurnal Sosial Ekonomi Pertanian, $0(1), 1-23$.

Antara, M. (2008). Dampak Pengganda Usaha Kecil Sektor Pariwisata terhadap Pertumbuhan Perekonomian Bali: Suatu Pendekatan Model Input-Output. SOCA: Jurnal Sosial Ekonomi Pertanian, 8(2), 1-24.

Antara, M., \& Sumarniasih, M.S. (2017). Role of Tourism in Economy of Bali and Indonesia. Journal of Tourism and Hospitality Management, 5(2), 34-44.

Badan Pusat Statistik. (1999). Kerangka Teori dan Analisis Tabel Input-Output. BPS. Jakarta.

Badan Pusat Statistik. (2019). Berita Resmi Statistik. BPS. Jakarta.

Chenery, H.B., \& Watanabe, T. (1958). International Comparisons of the Structure of Production. Econometrica, 26(4), 487-521. 
Chen, Z., Liu, Y., Zhang, Y., \& Zhong, Z. (2020). Interregional Economic Spillover and Carbon Productivity Embodied in Trade: Empirical Study from the Pan-Yangtze River Delta Region. Environmental Science and Pollution Research, 28, 7390-7403.

Daryanto, A., \& Hafizrianda, Y. (2010). Analisis Input-Output dan Social Accounting Matrix untuk Pembangunan Ekonomi Daerah. IPB Press. Bogor.

Muchdie. (1998). Keterkaitan Sektor-Sektor Pariwisata dalam Perekonomian Bali: Analisis Input-Output. Majalah Ilmiah Ilmu dan Wisata, 18(Okt 1998), 12-25.

Purwanti, P.A.P. (2002). Analisis Keterkaitan Sektoral dan Dampak Pengganda dengan Pendekatan InputOutput: Studi Kasus Provinsi Bali, 1993 dan 2000. Tesis Universitas Gajah Mada. Yogyakarta.

Rasmussen, P.N. (1958). Studies in Intersectoral Relations. North-Holland PC. Amsterdam.

Setiawan, I.D.M.D. (2007). Peranan Sektor Unggulan terhadap Pertumbuhan Ekonomi Daerah Jawa Timur, Bali, dan Nusa Tenggara Barat: Pendekatan Input-Output Multiregional. SOCA: Jurnal Sosial Ekonomi Pertanian, 7(2), 1-23.

Tsukamoto, T. (2019). A Spatial Autoregressive Stochastic Frontier Model for Panel Data Incorporating a Model of Technical Inefficiency. Japan \& the World Economy, 50, 66-77.

Yuendini, E.P., Rachmi, I.N., Puspitasari, N.N.A., Harini, R., \& Alfana, M.A.F (2019). Analisis Potensi Ekonomi Sektor Pertanian dan Sektor Pariwisata di Provinsi Bali Menggunakan Teknik Analisis Regional. Jurnal Geografi, 16(2), 128-136. 